\title{
The Meaning of Communication in Fashion Style of Muslim Student in Institut Agama Islam (IAI) Al-Aziziyah Samalanga Bireuen Aceh
}

\section{Saiful Bahri}

Institut Agama Islam (IAI) Al-Aziziyah Samalanga Bireuen Aceh, Indonesia tgkdrsaiful@gmail.com

\section{Abstract}

Changes in Muslim fashion trends will not be dammed and will continue to experience changes. Different from the previous year, where the trend of Muslim clothing in Indonesia tends to show an experimental trend. This year, the experimental trend has shifted to a long head covering known as the hijab syar'i. The term shari'i used, refers to Muslim women's clothing where the clothes, according to the Islamic Shari'ah guidance. Therefore, many call this ongoing fashion trend with shar'i hijab. Moving on from that thought, the problem to be investigated in this research is the meaning of Muslimah fashion communication style for AlAziziyah Samalanga Bireuen Aceh's Islamic Religion Institute (IAI) students. To uncover the problem thoroughly and deeply, this study uses a qualitative descriptive method that is useful for providing data and facts about the meaning of communication in the style of Al-Aziziyah Samalanga Islamic Institute (IAI) student dress style. Then the data were analyzed with the basis of the thought of George Herbert Mead and the principle of George Ritzer, in order to obtain a deep meaning about the student's fashion style. Meaning is produced from religious background, motives, and social environment. After that, meaning is modified through an interpretive process, and then individuals develop self-concepts through interactions with others. Self-concept provides an important motive for behavior and expression in choosing a style of dress. From the results of the study it was found that the meaning of communication style of Muslim female students of the Islamic Religious Institute (IAI) Al-Aziziyah Samalanga was produced from a background of religiosity, motives, and social environment. Then, individuals do the process of self-communication and produce a meaning that is interpreted through clothing. Some of the meanings of communication of Muslim female student fashion styles The Islamic Religious Institute (IAI) Al-Aziziyah Samalanga are produced based on the female Muslim students' fashion styles, namely: The meaning of Muslimah women's fashion styles as self-identities, the meaning of Muslimah women's fashion styles as a lifestyle, and the meaning of Muslim women's clothing styles as a form of obedience. Fashion communication is produced through the use of various symbols and fashion styles, so that the attitudes and behaviors of the user are reflected and generate direct appreciation through the interaction of people around. Several ways of meaning female students of communication style of Islamic clothing Islamic Institute of Islam (IAI) Al-Aziziyah Samalanga communicates Muslim clothing styles: Dressing in one color from top to bottom, fashion that is in accordance with Islamic law and ignores the trend of the times, follows the trend of Muslim fashion at the time that, dress in colors, mix and match the color of clothing.
Keywords

clothing, fashion style; gender, communication

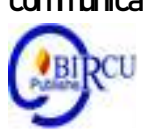




\section{Introduction}

The tradition of Muslim dress is a phenomenon which is rich and full of meaning, borrowing the term Geertz has become a kind of belief and handle life. He is considered part of the great tradition contained in Islam. But more than that, Muslim clothing functions as a language that tells social messages in culture. The tradition of Muslim clothing at the beginning of its presence is an affirmation and formation of one's religious identity. In its development, the meaning of Muslim fashion undergoes a significant shift in meaning. Muslim clothing does not only have a function as a symbol of religious or religious identity, but has entered the cultural, social, economic and even fashion domains, in other words Muslim fashion becomes a complex phenomenon. It does not only become a cultural identity. In this context, Muslim clothing becomes an object of interpretation that is rich in meaning. This kind of thing will be easily found in social life.

The rapid development of the use of Muslim clothing has provided a change in the meaning of wearing Muslim clothing. If at first using Muslim clothing is a form of one's obedience to God's rules, in its development using Muslim clothing reaches the other side of the function of dressing in Islam.

Changes in Muslim fashion trends will not be dammed and will continue to experience changes. Different from the previous year where the trend of Muslim clothing in Indonesia tends to show an experimental trend. This year, the experimental trend has shifted to a long head covering known as the hijab syar'i. The term shyar'iused, referring to Muslim women's clothing where the clothes, according to Islamic Shariah guidance. Therefore, many call this ongoing fashion trend with shar'i hijab.

The tradition of Muslim dress is a phenomenon that is rich and full of meaning, borrowing the term Geertz. Has become a kind of belief and handle life. He is considered part of the great tradition contained in Islam. But more than that, Muslim clothing functions as a language that tells social messages in culture. The tradition of Muslim clothing at the beginning of its presence is an affirmation and formation of one's religious identity. In its development, the meaning of Muslim fashion undergoes a significant shift in meaning. Muslim clothing does not only have a function as a symbol of religious or religious identity, but has entered the cultural, social, economic and even fashion domains, in other words Muslim fashion becomes a complex phenomenon. It does not only become a cultural identity. In this context, Muslim clothing becomes an object of interpretation that is rich in meaning. This kind of thing will be easily found in social life.

The rapid development of the use of Muslim clothing has provided a change in the meaning of wearing Muslim clothing. If at first using Muslim clothing is a form of one's obedience to God's rules, in its development using Muslim clothing reaches the other side of the function of dressing in Islam.

Changes in Muslim fashion trends will not be dammed and will continue to experience changes. Different from the previous year where the trend of Muslim clothing in Indonesia tends to show an experimental trend. This year, the experimental trend has shifted to a long head covering known as the hijab syar'i. The term shyar'i used, referring to Muslim women's clothing where the clothes, according to Islamic Shariah guidance. Therefore, many call this ongoing fashion trend with shar'i hijab.

In the sociology of communication explained that communication as a the process of interpreting carried out by someone on the information, attitudes, and behavior of others in the form of knowledge, gestures or attitudes, behaviors, and feelings so that someone makes 
reactions to the information, attitudes, and behaviors based on experiences that he has ever experienced.

Communication is something that is very natural that we usually experience

and we do not realize that it creates a collective similarity that affects our thinking about communication. Communication states that a thought, a meaning, or a message is held in common.

Communication as the creation of meaning, symbolic transactional processes that involve people give meaning. A general interest in communication has developed rapidly in this fast-moving world. We tend to give an assessment of someone on first impressions. Someone can trust us, like us, want to do business with us, and much more after seeing our appearance. From this it can be said that clothing or fashion style or fashion is a communication activity. Intentional or not, people who see or interact with us will receive messages and give an assessment of the clothes we use.

According to Allan Pease in his research stated that the role of words only lasts from $7 \%$ to $10 \%$ of the total impact, the sound of $20 \%$ to $30 \%$ of the total impact, while body language can affect $60 \%$ to $80 \%$ of the total impact. For Allan, how to look, smile, behave, and dress can have the most influence on someone. And one's appearance will be far greater and more important representing the way people communicate.

Kefgen and Touchie stated, clothes can convey messages, clothes are seen before the sound is heard, clothes certain relates to certain behaviors. In general, clothes or clothing we use to convey our identity, to reveal to others who we are. Conveying identity means showing others how our behavior is and how others should be treat us. Besides clothing is used to convey feelings, status and role, as well as formality.

Many messages are communicated through fashion, clothing is an integral part of life. Fashion becomes media to exist expressions and ideas that sometimes appear in an abstract form. This style of order and guidance is interpreted as an effort to express the desire and recognition of identity in the context of life. Expressions in the style, making, and wearing of certain styles encourage some personal to provide the limits of clothes that are comfortable or not, appropriate or not, to be worn and seen by others.

Stylish clothing, especially Muslim clothing in life becomes a kind of trend. Is a personal choice, participate in fashion trends and dress in accordance with the wishes., The use of Muslim clothing and modification of Muslim clothing can create a variety of reciprocal communication inside it. This clearly happened to students of the Islamic Institute of Islam (IAI) Al-Aziziyah Samalanga Bireuen Aceh, where the current fashion trends have influenced the way they dress. Look their fashionable and slang for example. Even though one side is confronted with the issue of code of conduct on campus, which is based on Islamic religion.

But as if, the desire to communicate, express, the desire to exist has driven them to carry out symbolic communication with diverse and trended fashion styles; as they say: "Islam does not mean slang". Looking at the background of the issue of fashion style of Islamic Students Institute of Islamic Religion (IAI) Al-Aziziyah Samalanga Bireuen Aceh such as not wanting to miss the trend or style of Muslim clothing that they wear, various trends or styles of Muslim fashion that develop, and automatically create a variety of messages which can be delivered by a student of the Islamic Institute of Islam (IAI) AlAziziyah Samalanga Bireuen Aceh. 


\section{Review of Literatures}

\subsection{Overview of Perceptions and Meanings of Communication}

\section{a. Communication Perception}

John R. Wenburg and William W. Wilmot's Definition: "Perception as a way for organisms to give meaning, Rudolph F. Verderber" perception is the process of interpreting sensory information. Brian Fellows: Perception is a process that allows an organism to receive and analyze information. Kenneth K. Sereno and Edward M. Bodaken: Perception is a means that allows us to gain awareness of our surroundings and environment. Philip Goodacre and Jennifer Follers: Perception is a mental process used to recognize stimuli.

Joseph A. De Vito: Perception is a process that makes us aware of many stimuli that affect our senses. Perception includes sensation or sensation which includes our sense organs (sense of touch, sense of sight, senses smellers, sense of taste, and listener senses), attention, and interpretation. Sensation refers to messages sent to the brain from the environment and the meaning of messages sent to the brain must be learned to be interpreted.

\section{b. Meaning of Communication}

The origin of the word communication is communis, which means common (common) and then etymologically defined as "the process that makes it the same for two or more people who were once the monopoly of just one or a few people". Therefore, one clear characteristic of meaning relevant to human communication is "togetherness". The meaning related to communication is essentially a social phenomenon. The meaning includes a variety of understandings, including more than just the interpretation or understanding of an individual.

1. Meaning According to the Perspective of the Mechanism

The meaning can be different and depend on the communicative function contained in the message at each point on the channel, both inside and out outside the channel. Assume that meaning is in a message or even deep the information contained in the message oversimplifies the mechanistic perspective. Information must be transformed, for example encoded or interpreted. At each channel point where the transformation or interpretation takes place, the meaning can be predictably different. In addition, interference with the channel from both inside and outside will result in a loss of trust level of the message.

The meaning of the message in a mechanical perspective depends on the delivery or receiving messages on the channel. The problem of delivering information that is transformed from one way to another and the problem of disruption including disturbances of wrong meaning is a problem that directly comes from the focus of the mechanistic perspective where meaning is always different from one point to another when the message flows along the channel.

2. Meaning in the Perspective of Psychology

The meaning is in people or meaning is perception or people not words, which is meaningful. The meaning of an internalized conceptual filter is the result of personal experience in the past. Affirmation patterns are has been experienced by individuals, all associations of the past. Communication occurs as long as the meaning of the utterance is related to the meaning interpreted. Because both are conditioned responses, communication success depends to what extent the similarity of past communication experiences.

Communication includes the reception of stimuli through the senses, filtered by the communicators' perceptual devices, and communicative responses, also filtered by "internalized" devices. Interpretation of stimuli and responses given by two or more communicators can only be the same as long as their devices are the same conceptual filter. 
Central to the conceptualization of meaning in the psychological perspective of human communication is the concept of isomorphism, which means that there are similarities of organisms originating from different offspring. If applied in communication, isomorphism shows the similarity of meaning in two people because of the similarity of past experience and similarity in their perceptual devices. Psychologically diverse meanings depend on similarities and conceptual filters and past experiences in the individuals who are communicating. The result is a variety of meanings, maybe the same but an explanation about the results theoretically or philosophically different intrinsically in a mechanistic and psychological perspective.

3. Meaning from the Perspective of Interactionism

The interactional perspective sees itself as a social creation that is only achieved through communication with others. Meaning is the creation of social situations and the premise of any social relationship is a set of meanings together. Mead places interactional meaning on a gesture conversation, where a gesture means potentially meaningful action.

Thus, meaning occurs as a "triangular relationship between one's cues, responses to those cues by the second person, and the completion of certain social actions initiated by the second person's cues, and the completion of certain social actions that are initiated by the cues of the first person.

This perspective discusses togetherness or sharing meaning through active participation in the communicative process. Interactionism places meaning outside the individual within the communicator's behavior or cues. However, a great sense of dependence on internal concepts such as empathy, identification, and understanding states that many communicative processes involving the concept of meaning still remain in the individual concerned. And even then, individuals are both products and participants

in social situations.

4. Meaning from the Perspective of Pragmatism

Meaning according to the pragmatic school is a selective function that is carried out on the range of choices available to the communicator. The sequence of actions that is patterned by the frequency of the recurring patterns, illustrates how and why meaning arises as a product of the social system developed during the interaction.

McHugh illustrates that the communicative meaning during social interaction has a strong pragmatic tone, where he found that the subjects (research) often create meaningful settings or situations in interaction even under anomalous conditions or without controlled norms ie, the absence or absence of an atmosphere that is meaningful. Meaning is formed and developed during social interaction.

Liklider explained the meaning as a social process of modeling. He stated that communication is a joint activity of two people

or more being a joint model, creating, exploring, comparing, modifying, adjusting, and evaluating the model in a manner together. Therefore, the meaning in communication is a model resulting from social interactions that are mutual give and take, which allows and even demands the individuals involved in it to adjust themselves to others, do so, and also with the social system.

Because the meaning (the formation of a model) as a concept of communication is not the product of or owned by each individual, he is an inherent creation of individuals who join are formed only through interaction with other people. That's why meaning is a product of and owned by the system social as a whole. And besides that, the meaning is reflected in and expressed by the patterning of social interactions that are marked with there is a sequence of actions that occur repeatedly. 


\subsection{Overview of Muslim Clothing Styles}

According to Malcolm Barnard, author of Fashion As Communication, the main function of clothing is to hide body parts that should not be shown to others and protect us from various situations and conditions. In general, the function of clothing or clothing to protect the human body. The material used is also very diverse because it is usually sourced in the surrounding natural conditions. Fashion is also an expression of art and beauty. Therefore, fashion does not merely meet basic human needs, but also become one of the container for expression.

\section{a. Understanding Muslim Clothing}

The history of fashion was born along with the history of human civilization. Therefore, fashion has existed since humans were created. Clothing has so many functions, namely closing certain members of the body to the decoration the body as explained in the Qur'an which implies the function of clothing; "O son of Adam (man), in fact we have lowered you clothes to cover your body's nakedness and for jewelry".

The consequence of being a religious man is to try as much as possible to carry out all the commands of Allah and leave all His prohibitions. One form of Islamic religious instruction is the command to wear clothes that cover all parts of the genitals that are not appropriate to be shown to other people who are not Muslims.

Muslim clothing is clothing that is in accordance with Islamic teachings, and the user of that clothing reflects a Muslim woman who is obedient to the teachings of her religion in the manner of dress. Muslim fashion is not just a symbol but by wearing it means that a woman has proclaimed to Allah a creature of belief, her views of the world, and the way of life that she takes. Where all that is based on a deep belief in God Almighty and Powerful.

\section{b. Criteria for Muslim Clothing}

There are five points that become criteria for Muslim clothing according to the Shari'a, namely as follows:

1) Muslim clothing must cover the entire body from the view of men who are not mahram. And he should not open to his mahram man except the part which is according to proper and proper habits (not including husband). One way to cover genitals besides wearing clothes is for a Muslim woman to wear a headscarf (holding out her hijab). Allah Almighty says: Meaning: "O Prophet say to your wives, your daughters and the wives of the believers: let him extend his veil throughout his body. That is so that they are easy to recognize, therefore they are not disturbed. And Allah is Forgiving, Most Merciful. (Surat al-Ahzab: 59) Umm Salamah ra. said: so down this verse he should extend his veil throughout his body. Al-hafizh Ibn Kathir explained: "The word of Allah instructed His Messenger that he commanded women of faith, especially girls and wives because of their glory, to extend their headscarves so that they differed from ignorant women and female slaves. What is meant here is not limited by name, type, and color, but the hijab is all clothes that can cover the points of women's jewelry. The hijab is more perfect than using the word al-khimar (head covering / veil) because it covers the entire female body and covers the entire upper part of her body including jewelry or something that depicts (shape) her body. Because clothes that describe a woman's body size are haram in use in the presence of non-mahram men.

2) The clothes that Muslim women wear cover what is behind them. The point is not thin dreamy so that the color of his skin can be seen from the outside. The term closes will not be realized except with thick cloth. If it is thin, it will increasingly provoke slander (temptation) and means revealing jewelry. From Abdullah bin Abu Salamah, it was said 
that Umar bin Al-Khattab had worn a qubthiyah dress, (a type of clothing from Egypt that was thin and white) then Umar said, "Don't you wear these clothes for your wife! "Someone then asked," O Amirul Muminin, I have used it to my wife and I have seen at home from the front or back, but I do not see it as thin clothing. "Then Umar answered," even though it is not thin, but he does characterize (describes curves).

3) Clothing does not strictly shape body parts. Usamah bin Zaid once said, "Rasulallah gave me a thick qutbiah shirt and it was a shirt that had been given by al-kalbi to him. Even then, I wear clothes to my wife. The Prophet asked me, why are you not wearing the Qutbiyah dress? I answered I was wearing the clothes to my wife. The Prophet then said: "Order him to wear the underwear behind the quthbiyah, I am afraid that the clothes can still describe the curve of his bones.

4) Muslim women's clothing does not resemble men's clothing. There are several hadiths that curse women who are liking themselves to men, both in terms of clothing and others. Abu Hurairah said that the Prophet cursed men who wore women's clothing and women who wore men's clothing. In this hadith contained clear instructions about the prohibition of actions of women like men and vice versa this is general, including clothing and other issues. Clothing worn by women does not have decorations that can attract people's attention when going out of the house, so it is not classified as women who like to appear with jewelry. A woman who likes to show her jewelry can be said to be a dandy or tabarruj woman, said tabarruj for women has three meanings:

a. Showing the beauty of the face and the points of body charm in the presence of nonmahram men.

b. Showing the beauty of clothes and their attention to non-mahram men.

c. Showing the style of walking, the swing and the swinging on in front of non-mahram men.

As in the word of God which means: "And do not decorate and behave like the ignorant people". (Surah Al-Ahzab: 33) Allah says, which means: "And let them not show their attention except that which may be seen from them". (Surat An-Nur: 31). The evidence forbidding tabarruj from the hadith of the prophet is narrated from ABU Hurairah ra: rasullah saw said, which means: "There are two classes of inhabitants of hell that I will not see: people who have a whip like the tails of the cows they use to whip people (with all mena) and women who are dressed but bare, swaying seductively teasing, their heads are like humps that swerve. They will not enter heaven nor will they smell it."

5) In terms of color, not too flashy so it attracts parhatian (lust) of the opposite sex. Looking neat and attractive is not always by decorating and striking appearance. Cleanliness, neatness, and nature will reflect the true personality. Formerly fashion is a primary requirement. As the world of information and technology develops, the style of dress becomes a medium to show one's existence.

By following a certain fashion style, a person can show his true identity. This shows that the current style of dress has become part of one's lifestyle. The style of dress always changes. The changes that occur are more rapid than other aspects such as other fields in human activities such as language, thought, and others.

\section{Research Methods}

To uncover the problem thoroughly, this study uses a qualitative descriptive method that is useful for providing data and facts about the meaning of communication that exists in the style of Al-Aziziyah Samalanga Islamic Institute (IAI) student dress style. Then the data were analyzed with the basis of the thought of George Herbert Mead and the principle of 
George Ritzer, in order to obtain a deep meaning about the student's fashion style. Meaning is produced from religious background, motives, and social environment. After that, meaning is modified through an interpretive process, then individuals develop self-concepts through interactions with others. Self-concept provides an important motive for behavior and expression in choosing a style of dress.

\section{Results and Discussion}

\subsection{Results}

In a study conducted from 3-31 December 2019, researchers obtained data on various meanings and styles of Muslim communication that existed at the Al-Aziziyah Samalanga Institute of Islamic Religion (IAI). This research focuses on the meaning of fashion communication for students of the Al-Aziziyah Samalanga Institute of Islamic Religion (IAI) and how they communicate the style of Muslim clothing used.

The first informant represented a female student while he was a student, he was one of the students of the Al-Aziziyah Samalanga Islamic Institute (IAI). The woman who studied at the Da'wah and Communication faculty, this 3rd semester PMI study program was a category of women who were very concerned fashion style. He likes to wear clothes starting from the veil, clothes, pants, shoes / sandals and accessories of the same color. Like her. He likes and likes.

Unlike one of the participants who did not stay in a dayah to buy colorful clothes so that it looks strange because it is not in hours of study. In addition, it can also be recognized a person's personality. Informant who happened to be wearing red clothes all the time saying because:

"I don't like to see girls with colorful colors, like clothesline. So the one who looks at him is not clear personality. Lek like this is good, red veil, red shirt, red pants, red shoes, red wristbands, my eye shadow is red too. So it looks like you have personality."

The next informant was a student who did not live in his father's house, but seemed more deceptive in dressing. The researcher knew this informant from an informant who had been interviewed by researchers. This informant is one of the students of the Islamic Institute of Islam (IAI) Al-Aziziyah Samalanga who uses a long and wide Muslim fashion style. He has his own perspective in choosing clothes after attending the recitation. For him, appropriate clothing is used in accordance with Islamic law. He is a figure who has high religiosity, very concerned about the teachings of Islam, including procedures for dressing in Islam.

"I used to live for 3 years ustazah, right at the time of the Koran, my ustad explained that good clothing and hijab are loose, thick, and the colors are not conspicuous. Hijab that covers the chest as in the Qur'an surah al-ahzab: 59. In addition there is one of my friends who supports me to carry out the teachings of Islam in a dress like this miss. And after I tried, Alhamdulillah, it turned out comfortable with me. Alhamdulillah, I have also been able to do istiqamah until now."

According to another informant, his family is not a family that is too Islamic or wears Islamic clothing, so the family is not the reason for him use a long fashion style and in accordance with Islamic law. This female student's fashion style attracted the attention of researchers, so researchers chose to become informants. Long and large hijab, long clothes, and skirts became the style of everyday dress, especially in college. According to him, the 
hijab and clothes that are true for women, that is, loose are not tight, cover the whole curve of the body, and the color is not striking.

"Alhamdulillah ustazah, I like this fashion style. Because in my opinion, the right outfit is in accordance with Islamic teachings. Long veil covering the chest. I am not interested at all with the up-to-date fashion style at the moment, instead I see it strange. The problem is that it is just as damaging to Islam, right now the headscarves and clothes are too tight and the material is thin. That is not appropriate for example and is not true according to Islam, miss. What is certain is "ati 'ulloha wa ati' urrosul, this is the command of Allah and His Prophet". My goal to dress like this is the main because it is in accordance with the teachings of Islam, ya, and by dressing like this, it can be a da'wah field, hopefully there is something to imitate. And Alhamdulillah, many of my friends joined in my kayak dress. Alhamdulillah also dress like this in accordance with myself miss."

The fourth informant, this woman is very close to researchers. So the researchers only did a little interview about the condition of the family and their background. From observations of researchers who have known them for years, it makes it easier for researchers to obtain the data needed. This informant is a fashionable female student, no fashion trends are out of her reach. Currently, the process of working on a thesis is the same as a researcher. He is a KPI Study Program, semester 7. After studying at IAI Al-Aziziyah, inevitably he must dress according to the code of ethics for fashion on campus.

"Yes, dear, I really like to follow the trends so it looks fashionable. I was a little less interested in the width of Muslim clothes. Just for the holidays I bought Muslim clothing. So I will just follow the Muslim fashion trends, so I will still be okay. Especially now that it's a good model."

This friend or informant has a unique personality and Swedishness. Since many friends who commented on their fashion style, he changed his style and followed a fashion style that was the right choice according to him to look beautiful and attractive.

With a variety of styles of dress that the current trend is not make all the students join in to dress like that. Religiosity background is a big influence in choosing the style of Muslim clothing of each individual. As from the results of interviews and observations that have been conducted by researchers, that student religiosity has a percentage very different. Students who although they had previously studied at Islamic boarding schools / dayahs were different in interpreting the results of the symbols they received when interacting or communicating. Likewise with female students who have never smelled the scent of an Islamic boarding school/dayah.

The various meanings and communication of Muslim fashion that researchers get at the time of the study and the results of in-depth interviews. The researcher concludes that the meaning of fashion for the Al-Aziziyah Samalanga Institute of Islamic Religion from the results of the interaction of each individual is based on 3 factors, namely the background of religiosity, motiv, and social environment.

Students who had previously studied and lived in Islamic-based Islamic dayah schools meant that Muslim clothing should be poly and cover the entire body so that the shape of the body was not visible. Meanwhile, female students who did not know the environment or studied without Islamic values considered that Muslim clothing, wearing the hijab and looks still fashionable without regard to Islamic law. Muslim clothing that is in accordance with Islamic teachings or clothing that does not care about Islamic law which is the choice of 
female students in fashion shows that the religious background of each individual is one of the factors influencing students to choose their fashion style.

Motivation, Al-Aziziyah Samalanga's style of Islamic student (IAI) dress style is also influenced by individual preferences and tastes. Maintaining self-existence, attracting, more confident, trend setter and being the center of attention are motivated by Al-Aziziyah Samalanga Islamic Institute students (IAI) based on available data.

Social environment, the existence of the code of ethics of the Institute of Islamic Religion (IAI) Al-Aziziyah Samalanga in dressing while doing learning activities, making all the female students wore the hijab and covered their clothes. From any country, city or background, female students must dress if they are Muslim became a student of this one institute. From some of the data obtained, there are students who actually don't like to wear the hijab, then wear the hijab because the code of ethics in the campus makes it forced to dress in Muslim fashion. In addition to the code of ethics, following the trend also supports female students in choosing fashion styles. From this code of ethics and trends, it can be said that the social environment is one of the factors of the Al-Aziziyah Samalanga Islamic Institute (IAI) student in choosing fashion styles.

When the researcher was at the research site, the Islamic Institute of Islam (IAI) AlAziziyah Samalanga found that the style of student attire differed although they were equally veiled (Islamic). So that meaning is also presented a variety, according to background and experience as well as different ways of interacting. But the meaning they take is not only the result of personal background, motives and experiences but also influenced by interactions with people around them which they then express with the style of clothing they have chosen accordingly with each individual's desires.

From several informants who have successfully interviewed and observed as well as observation, female students use Muslim-style clothing because of 3 factors, the first is the social environment namely the code of conduct dress in the Al-Aziziyah Samalanga Institute of Islamic Religion (IAI). the second, the background of religiosity of each individual, and the last is the motive.

The social environment greatly influences the style of Al-Aziziyah Samalanga Islamic Student's Institute of Islamic Studies (IAI). As in the implementation of the code of conduct dress that is applied by the campus while in the campus environment. The code of ethics is a rule that must be obeyed by all students of Islamic Religion Institute (IAI) Al-Aziziyah Samalanga, therefore the code of ethics is a major factor in all female Muslim students. Many of the female students are not veiled and dressed in Muslim clothes when they are outside campus everyday. But then they changed to Muslim fashion style while on campus. As one informant said during the interview:

"To be honest, I don't like wearing Muslim clothes or even wearing a hood every day. For example, if I don't have to wear a veil here, I prefer not to have a veil."

But not all female students have a motive because of the code of ethics on. The results of the data also said that there were female students who dressed in Muslim fashion like real Muslim women, they wore Muslim clothing because of their previous religious background. So this student uses Muslim clothing from the heart and is sincere. As an excerpt from the interview:

"What is certain is" ati 'ullaha wa ati' 'urrasul, this is the command of Allah and His apostles. The purpose of my dress like this is the main because it is in accordance with Islamic teachings." 
From the Muslim manner of dress, also the way of speech is reflected and his behavior also illustrates the Muslim piety. It can be ensured that the same social environment can produce different meanings to the clothes they wear. This explains that it is not only the social environment that can influence female students in fashion.

As has been explained above, the factor of the level of individual religiosity and personal motives also influences the style of dress. The data obtained by the researchers illustrate that, students of the Islamic Institute of Islam (IAI) Al-Aziziyah Samalanga are individuals who have different characters and personalities. Very visible in the style of dress that includes a variety of styles and the way they express it. At first glance all the female students were dressed in Muslim attire because they wore a veil (hijab), thus bringing up a deep Islamic meaning. However, if you look further, it is actually what can form the style of dress that is, the factors which illustrated in the following schema.

The data analysis results above show that meaning can be formed from a background of religiosity which consists of informant profiles, family descriptions, and conditions is forming environment. Motives consisting of tastes or preferences and the existence of each individual. Finally, the social environment from the code of ethics and trends that existed at that time. And from the results of the process of meaning the female student shows or communicates through clothing chosen according to their desires and goals. So then messages appear that are received by people around who will give meaning to fashion style and the response to fashion wearers.

From the observations and interview results of the informants, the researcher found a finding that the clothing worn by the Al-Aziziyah Samalanga Islamic Institute (IAI) female student contained meaning that was immediately read, including:

\section{a. Cultural Meaning}

In most cultures, clothing differences between the sexes deemed appropriate for men and women. Difference in style, color and fabric also affect. Likewise in terms of models or forms of clothing. Where fashion has become a marker of certain societies. For example, Islam, indigenous peoples, certain social classes. Clothing has created a certain culture. So that with clothing the community is identified and categorized as a group.

Likewise, what happened in the context of the Al-Aziziyah Samalanga Institute of Islamic Religion (IAI), as an Islamic-based educational institution, inevitably Muslim clothing became fashionable and fashionable for the entire academic community. Especially the students who became the study of researchers. With the code of conduct he made. So from that outfit the campus (institution) is culturally identified with Islam.

In Western society, skirts, dresses, and high heels are usually seen as women's clothing, while ties are usually seen as men's clothing. Pants were once seen as special clothing for men, but currently worn by both sexes. Men's clothing is sometimes more practical than women's clothing (that is, they can function well in a variety of situations), but women's clothing is sometimes broader in terms of fashion and style than men's clothing. Men are usually allowed to be shirtless in various public places, such as in swimming pools.

Usually women are allowed to wear men's clothing. But on the contrary, men who wear women's clothes are often considered strange. In some cultures, laws govern what men and women should wear. The Islamic religion commands women to wear simpler forms of clothing, usually headscarves. However, in practice, what qualifies as simple varies in different societies, however, women are instructed to cover their bodies more than men. Like the burqa for Muslim women as a form of purpose of the simplicity of the veil. 


\section{b. Social Meaning}

In some societies, clothing can be used to indicate class or social status. In ancient Rome, for example, only senators were permitted to wear dyed purple tryan. In China, before the formation of the republic, only the emperor could wear yellow clothes. In this lawless society, which includes most modern societies, social status is not marked by the purchase of rare or luxury goods that are limited by costs to those with wealth or status.

Robe Alim Khan sends social messages about wealth, status and his power. In the middle east men can sometimes choose to wear men's skirts like togas or kilts, especially on ceremonial occasions. Such clothing (in earlier times) was often worn as normal everyday clothing with men. Compared to men's clothing, women's clothing tends to be attractive, often intended to seek men's attention. In modern industrial countries, women are more likely to wear colorful makeup, jewelry, and clothing, whereas in very traditional culture women are protected from the gaze of men in modest clothing.

The Al-Aziziyah Samalanga Institute of Islamic Studies (IAI) turned out to be inevitably reduced in the sense of fashion as above to social classes. In this case, female students (as objects of study) are in the perspective of certain social classes. From how to dress, color, style or fashion, they can be classified into certain social statuses. Either as a religious setting, motives, or social environment setting. For example, children of farmers, children of Islamic boarding schools / dayahs, and high school students, employees, etc. Which is how they dress to show their identity and from the environment where they actually come from.

\section{c. Religious Meaning}

Initially religious clothing might be considered as special clothing. Religious clothing is sometimes worn only during the performance of religious ceremonies. However, it can also be used daily as a sign of the status of special religion as a form of one's religiosity. However, in its development, clothing has escaped from the bondage of certain models and styles. Although on the other hand religion remains within a certain culture or stereotype claim. For example robes and veils, identified with terrorist groups. Or clothing 'you can see' is synonymous with glamor (hedonist).

In the case of Al-Aziziyah Samalanga Islamic Institute (IAI) female student, this also happened. For example, female students with large headscarves (headscarves) complete with veils, they are referred to as Right Islam or Hardline Islam. While the student movement is dressed as is; Long-sleeved shirts or shirts, ordinary headscarves are often considered left Islam.

But in the context of the meaning to be conveyed here the author is more

see the meaning of fashion has to do with one's improvement or understanding. If someone dressed in Muslim clothing, then he could be categorized as a religious person. The clothing gives meaning to the personal motives of each individual and the social environment in which he socializes and communicates. As in an interview with an informant follows: "What is certain

"Ati 'ullaha wa ati' 'urrasul, this is the command of Allah and His Prophet. My goal dress like this is the main because it is in accordance with Islamic teachings."

\subsection{Discussion}

In addition, there are basic ideas that refer to the problems of human groups, social interactions, objects, humans as actors, human actions and the interconnection of channels of action before humans choose fashion style: 


\section{a. The Nature of Society}

Basically, human society or groups in terms of this is a student of the Islamic Institute of Islam (IAI) Al-Aziziyah Samalanga being in action and must be seen in terms of action as well. The main principle of the theory what researchers use is anything empirically oriented towards humans, and no matter where they come from, they must pay attention to the fact that humans consist of people who are together in a social action and social social cohesion.

\section{b. The Nature of Social Interaction}

Social interaction is a relationship between one individual and another individual where one individual can influence other individuals so that there are mutual relations, or social interactions as relationships between people per person or with human groups. Society is a form of interaction between individuals. See the importance of social interaction as a means or as a cause for behavioral expression human behavior and actions.

\section{c. Characteristics of Object}

That the world exists for humans and their groups is composed of objects as a result of interaction. An object is something that can be indicated or shown. The same object has different meanings for different individuals. From the indication process reciprocity, general objects appear. Objects that have meaning the same for a group of people, will be seen in the same way by them.

\section{d. Humans as Acting Creatures}

Humans are essentially social beings since they were born, they need to interact with others to meet their needs biological, that is food, drinks, clothing and others.

Based on research data on the basis of theoretical views, researchers view humans as social beings in a deep sense, namely a creature that participates in social interaction with himself by making his own indications, and responding to a number of indications. In this sense, humans as creatures who participate in social interaction with himself, not a creature that only responds, but a creature that acts or acts, a creature which has to print a series of actions based on calculations, not only function release the response to existing social interactions.

\section{e. The Nature of Human Action}

Individual human beings are human beings who interpret themselves in the world this is so acting. Actions or actions for humans consist of calculations based on various things that he noticed and the appearance of a number of actions based on how he interpreted it. In these cases, a person must enter the process of introducing the culprit in order understand the action or action. This view also applies to joint or collective action where a number of individuals are taken into account. Joint action is the result of an interpretive interaction process.

\section{f. Relationship of Action}

Joint action from new situations, arises in a problematic group, where existing regulations are inadequate. It is the social process in group life that creates and enforces group life. Joint action refers to actions that change very much the life of a human group. From the results of the study, researchers saw that some of the clothing styles used by female students still did not meet the code of ethics and dress code according to Islamic teachings or commands. Like the statement of one of the informants:

"Yes, if I use this outfit I look pretty and sexy. I also more confident with this clothes like free rather than big clothes, that so great 
In fact, in the advice of Islam, there are five points that become clothing criteria Muslim women according to Sharia, namely:

1. Muslim clothing must cover the entire body from the view of men who are not mahram. But from the observation results there are still students who interpret that Muslim clothing only covering the hood or head cover.

2. Clothing worn by Muslim women closes what is behind it. The point is not thin dreamy so that the color of his skin can be seen from the outside. This is in line with the current fashion trends, many clothing models are dreamy and made of thin material. Researchers say this is because not a few of the students of the Institute of Islamic Studies (IAI) AlAziziyah Samalanga who use fashion styles from thin materials, especially students who are stylish to follow the trends (slang, trended).

3. Clothing must be loose, not reveal body parts. Lots of clothing that shows curves, although not rigid clothing such as clothing that is generally used by college students.

4. Muslim women's clothing does not resemble men's clothing.

5. In terms of color, not too flashy so it attracts parhatian opponent. This function becomes reversed as the times develop. Clothing which was originally a primary need and is a body protector and cover of genitalia makes clothing as a medium to attract attention (including the opposite sex).

Even from the overall results of the interview, the average goal of a fashion student is to get attention. One of them:

"It's very rare that you dare to mix and match these colorful clothes. So, I want to make my own trends besides that, I choose to dress like this so that many people want to know me and are interested in me."

Al-Qur'an has explained very clearly the function of clothing other than as a body covering and the meaning - the meaning contained in clothing, as in the letter Al A'raf: 26 which means:

"O children of grandchildren adam, in fact we have provided clothes to cover your nakedness and for jewelry for you."

The letter above shows that the function of clothing in addition to covering genitalia, clothing is jewelry. Which means that one of the functions of clothing is to beautify themselves and beautify themselves. Looking at the messages that can be conveyed by the style of dress, can produce a variety of responses including:

1. Be polite and respectful

"By dressed like this, I rarely teased a prankster miss. Yes maybe there are some who greet me when I pass by. Besides that, my friends are always polite when talking to me, miss. And that's in my opinion because of my clothes. "

2. Being the topic of conversation

"I've heard it, there are people who understand me. What people say I am tacky, not unmanned, not matcing. But let me leave it, it's up to them. The important thing is I like it and there are still many who admire me."

3. Praise

"Most guys who like me fee, so I tease me, say loc I" elastic."

From the interview results explained that the response is one form of communication results in dressing. The attitude shown by individuals who respond is their right to members responses based on the meaning of the symbol he saw. 
To produce a new theory or the development of an existing theory, the findings in this research are reviewed with theories existing and applicable in the world of science, especially communication science. As the next step in writing this thesis is a confirmation or comparison between findings and theory. Based on the findings in the study of Communication of Muslim Style Clothing of the Islamic Students Institute of Islamic Studies (IAI) Al-Aziziyah Samalanga, when confirmed between the findings of researchers in the field with the theory chosen by researchers in the study there was a match.

Symbolic interactionist theory is a relationship based on the exchange of symbols. Which means, humans interact with others by conveying symbols and giving meaning to these symbols.

The meaning in this study resulted from the background of religiosity, motives, and social environment. Of these three things, students of the Islamic Institute of Islam (IAI) AlAziziyah Samalanga produce a meaning through the process of self-communication which is then interpreted through the clothing they use. Behavior and style of dress someone is influenced by symbols given by others, as well as the person's behavior. Through giving signs in the form of symbols, it can express the feelings, thoughts, and intentions of the individual. And communication between individuals is as the core of forming the human personality. In other words, individual personalities are formed through communication with others and self-image is built through means of interaction with others. Like George Herbert Mead's theory which assumes that the real world is full of problems, and it is the function of the mind to try to solve problems and enable one to be more effective in life. Mead also views reason not as one thing, but as a social process. Even though there are people who act with the scheme of reaction action, but most human actions involve a mental process, which means that between action and reaction there is a process which involves thoughts or mental activities.

The mind also produces a sign language called symbol. Symbols that have meaning can be in the form of gestures or gestures but can also be in the form of a language. And the ability of humans to create language is what distinguishes humans from animals. Language makes humans able to interpret not just symbols in the form gestures or gestures, but also able to interpret symbols in the form of words. It is this ability that enables humans to be able to see themselves through the perspective of others where it is very important in understanding shared meanings or creating the same response to the same sound symbols.

Therefore, the ability to give answers to yourself like giving answers to others, is an important situation in the development of the mind. The body is not self, but it only becomes self when the thought has developed. In this sense, Self is not an object but a conscious process that has the ability to think, such as:

a. Being able to give answers to yourself like others who can give answers.

b. Able to provide answers such as rules, norms or laws that also provide answers to him.

c. Able to take part in one's own actions with others.

d. Being able to realize what is being said and the ability to use awareness to determine what needs to be done in the next phase.

Likewise in discussing the concept of The Self, George Herbert Mead always takes into account structural factors, namely society. Because basically according to Mead's observations, the concept of self (the self) determines the will, the desire, including the ambitions of beings called humans. But on the other hand the human self also has the conception of "Me", which takes into account the circumstances around him. "Me" is always influenced by internal interactions that are associated with the state of society. That's the social structure that affects the conception of the self. 
From Mead's thought above, it is clear that human actions are basically meaningful, involving interpretation, thinking and intentionality. Social actions are intentional actions, intentional for others and for the users themselves, whose thoughts are actively interpreting each other's behavior, communicating with each other and controlling their own behavior according to their communication purposes.

There are three basic ideas of symbolic interactions which are objects of research. Mind, namely the ability to use symbols that have the same social meaning. Each individual can develop their thoughts through interactions with other individuals who then experience the process with the personal self is the ability to reflect on each individual from the assessment of the viewpoints or opinions of others. And self process personally in symbolic interactionism theory which is one branch in sociological theory that suggests about themselves and the outside world then revealed to the community, social relations are created, built, and constructed by each individual in the community.

Each of these individuals is involved in the behaviors they choose actively and voluntarily, which ultimately leads humans to the decision making process in doing or in this context, namely in fashion. Humans act towards others based on the meaning given to them by others. Meaning is created in human interaction, Meaning modified through an interpretive process, individuals develop self-concepts through interactions with others, selfconcepts provide an important motive for behavior, people and groups are influenced by cultural and social processes, social structures are generated through social interaction.

Humans have the privilege and perfection. Able to accept all the stimuli or symbols that exist. Since childhood, the family, the environment, and the interactions carried out will shape the mindset of each individual, including in choosing fashion styles. Like the first principle of symbolic interaction according to George Ritzer, namely, humans do not seem to be lower than animals, humans are blessed with the ability to think.

From this social interaction, female students can cultivate thinking skills

to find a decision in fashion. In the principle of symbolic interactionism theory that thinking ability is formed by social interaction. With the privilege of humans given by God has the ability to think will accept the symbols received from social interaction absorbed in the mind. In social interaction, people learn the meanings and symbols that enable them to apply their unique abilities as human beings, namely thinking. The results of these interactions, teach humans about symbols which then appear according to individual abilities after doing the thought process.

Meanings and symbols allow people to continue actions and interactions. The meaning generated from these symbols can be expressed by each individual. Which means, after the female students find meaning, she will choose which one they will use as an action or action in fashion style. He is able to modify or change the meanings and symbols they use in actions and interactions based on their interpretation of the situation. Each individual is able to filter, choose and sort out which will be their actions. The symbols received will not be fully used by them in acting or dressing. They can and have the right to reduce, add, and change the meaning he gets. someone is able to make modifications and changes because, their ability to interact with themselves that allows them to examine the stages of action, assess the advantages and disadvantages, and then choose one of them.

After absorbing and weighing or communicating with themselves, individuals will choose one of the actions that is then taken. Because of their ability to think and interact with themselves, they can find new meanings according to the needs and preferences of each individual.

So from the analysis of links or data with theory, clothing is a basic human need besides food and shelter / residence (home). In principle, humans need clothes to protect and 
cover themselves. But along with the development of human life, clothing is also used as a symbol of status, position, or position (social class) of the wearer. The development and types of clothing a person depends on the customs, habits, and culture that is owned by the environment / region respectively. Clothing (clothing) also has a more substantial function, namely increasing self-esteem, increasing self-confidence, and individual security systems during one's activities. By giving messages to other people and the environment in which they are. Clothing also functions as a social marker of the exchange of symbols that take place during the communication process.

The basic thing about the main purpose of clothing (clothing) is to make the wearer feels comfortable. In hot climates clothing provides protection from sunburn or various other impacts, whereas in cold climates the nature of thermal insulation is generally more important. Clothing protects the body parts that are not visible. Clothing acts as protection from damaging elements, including rain, snow and wind or other weather conditions, as well as from the sun's heat. Clothing also reduces the level risks during activities, such as work or sports. Sometimes clothing is worn as protection from certain environmental hazards, such as insects, hazardous chemicals, weapons and contact with abrasives. Conversely, clothing can protect the environment from wearers of clothing, such as wearing masks.

Seeing the diverse functions of clothing, there are many findings of meaning obtained by the author in the case of the Al-Aziziyah Samalanga Islamic Institute (IAI) student, fashion has come out of its true function. In line with the development of the age of students of the Islamic Institute of Islam (IAI) Al-Aziziyah Samalanga increasingly stylish and fashionable. So clothing for them is not only as a body protector as sharia, for example, but further as a trend and fashion.

\section{Conclusion}

From the analysis that researchers have obtained from various informants and contributions from existing theories, the researchers concluded that the meaning of Muslim fashion style communication for female students of the Islamic Institute of Al-Aziziyah Samalanga Bireuen Aceh from the results of the interaction of each individual is based on 3 factors, namely religious background, motives, and social environment. Based on the theory of symbolic interaction, humans act on others based on the meanings given to them by others. Meaning is created in human interaction. The meaning is modified through an interpretive process, then individuals develop self-concepts through interactions with other people. Selfconcept provides an important motive for behavior and expression in choosing a style of dress.

Some meanings associated with individual motives, namely:

1) The meaning of religiosity, that clothing as a form of expression of faith.

2) Social meaning, that clothing as a form of symbolic expression is the meaning of interaction with the environment and other people (existential).

3) Cultural meaning, Clothing as a result of the search for creativity over one's expression through the exploration of the search for fashion and style, as well as clothing as a form of adherence to norms and rules agreed upon as a particular culture (such as the campus code of ethics). 


\section{References}

Agustin, Risa. Kamus Ilmiah Populer. Surabaya: Serba Jaya. 2007.

Barnard, Malcolm. Fashion Sebagai Komunikasi. Jalasutra . 2008.

Bungin, Burhan. Metodologi Penelitian Kualitatif. Jakarta: Raja Grafindo Persada. 2007.

Bungin, Burhan. Sosiologi Komunikasi. Jakarta: Kencana. 2007.

Hasbullah, Muntasir, Saiful Bahri, Riska Zahara, Zulfia, Messages Communication in the AlQur'an (Study of Messages in the Al-Qur'an for Believers), Budapest International Research and Critics Institute-Journal (BIRCI-Journal): Volume 2 No. 4, November 2019.

Helmi, Saiful Bahri, Riyandi, Nurazizah, Nurmasyitah, Implementation Place of 'Uqubat Canings in Fiqh Perspective (Analysis of Aceh Governor Regulation Number 5 of 2018), Budapest International Research and Critics Institute-Journal (BIRCI-Journal) : Volume 2 No. 4, November 2019.

(http://bircu-journal.com/index.php/birci/article/view/553/pdf)

Mulyana, Deddy. Metodologi Penelitian Kualitatif. Bandung: Remaja Rosda Karya. 2007.

Mulyana, Deddy. Ilmu Komunikasi. Bandung: Remaja Rosdakarya. 2012.

Muntasir, Saiful Bahri, Yusfriadi, Muttaqien, Ahmad Nidal, Fadlon, Human Communication with God through Asmaul Husna (99 Names of Allah) (Study of Asmaul Husna's Understanding in Islamic Theology), Britain International of Humanities and Social Sciences (BioHS) Journal : Volume 1 No. 2, October 2019.

(http://biarjournal.com/index.php/biohs/article/view/45)

Nasutian. Metode Research. Jakarta: Bumi Aksara Jaya. 2010.

Onong Uchjana Effendy. Dimensi-Dimensi Komunikasi, (Bandung: Remaja Karya, 1986.

Purwo,Bambang Kaswanti. Kajian Serba Linguistic. Jakarta: Gunung Mulia. 2007.

R.Bogdan, Taylor dan Biklen. Metode Penelitian Kualitatif,Panduan Teori, dan Praktek di Lapangan.Jakarta: Pusat Antar Universitas. 2007.

Rogers, M. Everett. Communication Technology, New York: The News Media in Society, The Fre Press, 1989.

Saiful Bahri, Hadiths About Communication Ethics (Study of Hadiths about Responsibility and Maintaining Information Accuracy), Budapest International Research and Critics Institute-Journal (BIRCI-Journal) Volume 1 No. 4, December 2018

Saiful Bahri, Maria Ulfa Batoebara. The Position and Participation of Khadijah in Developing Da'wah in Islam at the First Period. Budapest International Research and Critics Institute-Journal (BIRCI-Journal): Volume 3 No. 1, 2020. http://www.bircujournal.com/index.php/birci/article/view/745/pdf

Shodiq, Burhan. Engkau Lebih Cantik Dengan Jilbab. Solo: Samudra. 2007.

Singarimbun, Masri dan Sofian effendi. Metode Penelitian Survei, Jakarta: LP3ES. 2007.

Subagyo, P. Joko. Metode Penelitian. Jakarta: Rineka Cipta. 2013.

Syukur Kholil. Komunikasi Islam, Bandung: Ciptapustaka Media, 2007.

Syukur Kholil, Iskandar Zulkarnain, Saiful Bahri, The Existence of Public Relation in Constructing Image in Dayah MUDI MESRA Samalanga Bireuen, Aceh, Indonesia, IOSR Journal of Humanities and Social Science ( IOSR-JHSS), Volume 3, Issue 1 (Version V), Januari 2018.

Zulfikar, Saiful Bahri, Muslem, Fatahillah, Amiruddin, Muhibuttibri, The Da'wah Movement of Ulama Dayah (Analysis the Da'wah Movement of Têungkū Hasanoel Bashry), Britain International of Humanities and Social Sciences: Vol 2 No 1, February, (2020) http://biarjournal.com/index.php/biohs/article/view/146/170 